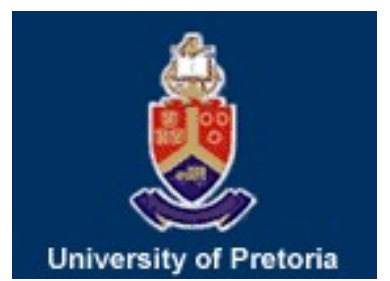

\author{
University of Pretoria \\ Department of Economics Working Paper Series
}

The Impact of Disaggregated Oil Shocks on State-Level Real Housing Returns of the United States: The Role of Oil Dependence

Rangan Gupta

University of Pretoria

Xin Sheng

Anglia Ruskin University

Renee van Eyden

University of Pretoria

Mark E. Wohar

University of Nebraska at Omaha

Working Paper: 2020-96

October 2020

Department of Economics

University of Pretoria

0002, Pretoria

South Africa

Tel: +27 124202413 


\title{
The Impact of Disaggregated Oil Shocks on State-Level Real Housing Returns of the United States: The Role of Oil Dependence
}

\author{
Rangan Gupta*, Xin Sheng ${ }^{* *}$, Reneé van Eyden ${ }^{* * *}$ and Mark E. Wohar ${ }^{* * * *}$
}

\begin{abstract}
We analyse the impact of oil supply, global economic activity, oil-specific consumption demand and oil inventory demand shocks on state-level real housing returns of the United States (US) over the monthly period of 1975:02 to 2019:12. We find that positive economic activity shocks and oil production shocks (associated with increase and decrease in oil prices respectively) increase real hosing returns. At the same time, oil-specific consumption and inventory demand shocks raise oil prices and reduce the state-level real housing returns. Moreover, across the shocks, the strongest effect originates from the global demand shock. In addition, the degree of oil dependency (oil consumed minus oil produced as ratio of oil consumed) does not change the nature of the impact of the four oil shocks on real housing returns drastically, but the size of the effects is relatively muted under low-oil dependence, barring the case of the oil inventory demand shock. Our results have important policy implications.
\end{abstract}

Keywords: Oil shocks, state-level real housing returns, oil dependency, local projection model, impulse response functions

JEL Codes: C23, Q41, R31

\footnotetext{
* Department of Economics, University of Pretoria, Pretoria, 0002, South Africa. Email: rangan.gupta@up.ac.za. ** Lord Ashcroft International Business School, Anglia Ruskin University, Chelmsford, CM1 1SQ, UK. Email: xin.sheng@anglia.ac.uk.

Department of Economics, University of Pretoria, Pretoria, 0002, South Africa. Email: renee.vaneyden@up.ac.za.

**** Corresponding author. College of Business Administration, University of Nebraska at Omaha, 6708 Pine Street, Omaha, NE 68182, USA. Email: mwohar@unomaha.edu.
} 


\section{Introduction}

Recent studies have highlighted the significant role of oil price and/or oil shocks on the movements of the house and real estate price and/or returns of the United States (US) within a single- or multi-country set-up that includes the US (Chan et al., 2011; Breitenfellner et al., 2015; Antonakakis et al., 2016; Nazlioglu et al., 2016, 2020; Agnello et al., 2017; Killins et al., 2017; Aye et al., 2019; Sheng et al., forthcoming). Different from these studies, Grossman et al., (2019) investigated the impact of oil price shocks on house prices in the largest urban centers in Texas, and showed that oil price shocks have limited pass-through to house prices, with the highest effects found among the most oil-dependent cities. We aim to build on the research of Grossman et al., (2019), by analysing the effect of structural oil shocks (oil-specific supply and demand, inventory accumulation, and global demand) on house prices of all the US states plus District of Columbia (DC), contingent on the oil dependency of these states. Given the evidence of the differential impact of oil price shocks across exporters and importers of oil (Baumeister et al., 2010; Bodenstein et al., 2012; De Michelis et al., 2020), the role of oil dependency of the US states, defined as oil consumed minus oil produced as ratio of oil consumed, could be an important variable (as will be evident in the next paragraph) in determining the impact of oil price shocks on the housing prices of the states. Note that, with house price serving as a leading indicator for the macroeconomy (Leamer 2007, 2015; Balcilar et al., 2014; Nyakabawo et al., 2015; Emirmahmutoglu et al., 2016), if the effect of oil price movements on house prices is contingent on the oil-dependency, then aggregate policy decisions would need to be designed keeping this dimension of the heterogeneity across the states in mind (Gupta et al., forthcoming; Van Eyden et al., forthcoming).

The existing literature dealing with oil and house prices highlight at least six channels underlying their relationship. First, the historically-established recessionary impact of oil price increases (Gupta and Wohar, 2017; Plakandaras et al., 2017) is likely to dampen the demand for housing, and hence, reduce its price, primarily for net oil consuming states. But such oil price hikes are likely to drive house prices up for the states that are net oil producers due to increased oil revenue resulting in a hike in housing demand. Second, oil price increases, are likely to increase construction and operational building costs in both net oil-exporting or oilimporting states, which might push house prices up due to a decline in the supply of housing. Third, tighter monetary policy to curb the pressure induced by oil price increases on headline inflation is likely to reduce liquidity from the housing market and hence, result in a fall in house prices due to a decline in demand for housing, irrespective of whether oil dependency is high or low. Fourth, if in the wake of inflation housing is used as a hedge (Anari and Kolari, 2002; Christou et al., 2018), the inflationary-effect of oil prices might actually end up increasing housing demand and hence, raise its price independent of the oil dependency status of the states. Fifth, following oil price hikes, investment opportunities in the oil sector, due to its financialization (Bonato, 2019), might lead to portfolio allocation away from housing, and thus affect its demand and price negatively, with this effect likely to be stronger for oil-rich states. Finally, both the oil and housing markets are likely to be driven by common factors such as economic growth. For instance, a booming economy can increase both house and oil price due to higher demand in the respective sectors, with the importance of this effect across the states being governed by the productivity increase being sectoral or overall. In sum, the impact of changes in oil prices on house prices is likely to be conditional on the oil dependency of the states.

At the same time, it is also important to understand, and as alluded to via the last channel discussed above, that not all oil price changes emanate from the supply-side, since there is a 
role of economic activity as well in driving oil prices, besides precautionary (oil inventory), and speculative (oil-specific consumption) shocks (Killian, 2009). Naturally, while analysing the impact of oil price movement on the housing prices of the US states, it is important to identify the underlying shock that has caused the oil price change, besides accounting for the issue of oil dependency of the US states. Against this backdrop, we estimate the impact of four structural oil price shocks on state-level house prices over the monthly period of 1975 to 2019, conditional upon their oil dependency, using impulse response functions (IRFs) generated from the local projection (LP) approach of Jordà (2005). In this regard, a smooth transition function approach is used to switch the oil dependence of states into high- and low-regimes within the LP framework. To the best of our knowledge, this is the first study to analyse the impact of oil price shocks accounting for oil dependency on state-level housing prices. The remainder of the paper is organised as follows: Section 2 discusses the data and methodology, while Section 3 presents the empirical results, with Section 4 concluding the paper.

\section{Data and Methodology}

\subsection{Data}

In terms of the house price data, we use the seasonally adjusted nominal house price data for the 50 states plus DC derived from the Freddie Mac, ${ }^{1}$ with the indices based on an everexpanding database of loans purchased by either Freddie Mac or Fannie Mae. To obtain the real house prices, the nominal values are deflated by the seasonally adjusted Consumer Price Index (PCE) derived from the Fred database of the Federal Reserve Bank of St. Louis. To ensure stationarity, we work with month-on-month growth rates of real housing prices. As far as the four structural oil-shocks, i.e., oil supply shock (OSS), global economic activity shock (EAS), oil-specific consumption demand shock (OCDS) and oil inventory demand shock (OIDS), are concerned, these are obtained from the structural vector autoregressive (SVAR) model of Baumeister and Hamilton (2019), ${ }^{2}$ who formulate a less restrictive framework (than what has been traditionally used in the literature following Kilian (2009)), by incorporating uncertainty about the identifying assumptions of the SVAR. In other words, the obtained oil shocks can be considered to be relatively more accurately estimated. Following De Michelis et al., (2020), we also construct a state-specific oil dependency series using US Energy Information Administration (EIA) data on oil production and oil consumption, with oil dependency defined as oil consumed minus oil produced as ratio of oil consumed for each state. ${ }^{3}$ Our effective panel dataset at monthly frequency ranges from 1975:02 to 2019:12.

\section{2. $\quad$ The Local Projection (LP) Method}

To examine the impact of various oil shocks on real housing returns of the US states, we employ the LP method proposed by Jordà (2005). The linear model for computing LP-based IRFs for a panel dataset is as follows:

$Y_{i, t+s}=\alpha_{i, s}+\beta_{s}$ Oil Shock $_{t}+\epsilon_{i, t+s}$, for $s=0,1,2, \ldots h$,

\footnotetext{
${ }^{1}$ http://www.freddiemac.com/research/indices/house-price-index.page.

2 The data is available for download from the research segment of the website of Professor Christiane Baumeister at: https://sites.google.com/site/cjsbaumeister/research.

3 Data for oil consumption and production at the state level are available from: https://www.eia.gov/state/seds/seds-data-complete.php?sid=US\#CompleteDataFile.
} 
where $Y_{i, t}$ represents the real housing returns at the state level $(i)$ in time $t, \alpha_{i, S}$ captures the fixed effect, $s$ is forecast horizon, $h$ is the maximum length of forecast horizons, ${ }^{4}$ Oil Shock $k_{t}$ represents an identified oil shock at time $t, \beta_{s}$ measures the response of real housing returns at time $t+s$ to an oil shock at time $t$. Each of the four identified structural oil-shocks is included one at a time in the model. The IRFs can be calculated as a series of $\beta_{s}$ estimated by the OLS method for each horizon $(s){ }^{5}$

Since our focus is on the response of real housing returns to oil shocks conditional on the status of oil dependence in the individual US states, following the work of Auerbach and Gorodnichenko (2013) and Jordà et al., (2020), we consider a regime-switching model which includes a smooth transition function $F\left(z_{t}\right)$, whereby the oil dependence of states switches between high- and low- states. The regime-switching model can be specified as below:

$$
\begin{aligned}
& Y_{i, t+s}=\left(1-F\left(z_{i, t}\right)\right)\left[\alpha_{i, s}^{R_{\text {high }}}+\beta_{s}^{R_{\text {high }} \text { Oil Shock }} t\right]+F\left(z_{i, t}\right)\left[\alpha_{i, s}^{R_{\text {low }}}+\beta_{s}^{R_{\text {low }} \text { Oil Shock }} t\right]+ \\
& \epsilon_{i, t+s} \text {, for } s=0,1,2, \ldots h \\
& F\left(z_{i, t}\right)=\exp \left(-\gamma z_{i, t}\right) / 1+\exp \left(-\gamma z_{i, t}\right), \gamma>0 \text {, }
\end{aligned}
$$

where $z_{i, t}$ is a switching variable measuring the oil dependence of the US states. It is normalised to have a zero mean and unit variance, with positive values of $z_{i, t}$ indicating high oil dependence, and negative values otherwise. The smooth transition function $F\left(z_{i, t}\right)$ is bounded between 0 and 1, with values close to 1 corresponding to the low oil dependence regime (denoted by $R_{\text {low }}$ ), and 0 otherwise (denoted by $R_{\text {high }}$ ).

\section{Empirical Results}

In Figure 1, we present the impact of the four structural oil shocks on the state-level real housing returns. The figure tracks the responses calculated by local linear projections to 1-unit increase of the disaggregated oil shocks on the future path of real housing returns for 1 to 12 month-ahead, along with the $95 \%$ confidence bands. The first observation that we can draw is that all the oil shocks have a statistically significant impact over the 1-year horizon. Next, we turn to the sign of the effect. We find that real housing returns rise following a positive shock to oil production, i.e., oil supply, with the effect staying positive over the entire forecast horizon of a year. A positive global economic activity shock causes real housing returns to increase initially for a quarter, with the sign fluctuating thereafter, ${ }^{6}$ but ultimately depicts a positive effect beyond 9-month-ahead. When we look at the oil-specific consumption demand shock, the effect is consistently negative for the entirety of the one-year-ahead forecast horizon. Finally, the impact of the oil inventory demand shock is initially negative for about two-months following the shock, before becoming positive and fluctuating with strong positive effect, before becoming negative after two-quarters (and turning positive at the end of the year). More importantly, the effects of the four oil shocks are in line with intuition. A decline in oil price due to increase in oil production, and expansion of global economic activity (and a likely booming US economy, given its importance in the world economic system) with oil price

\footnotetext{
${ }^{4} h$ is set to 12 , which corresponds to a 12 -month forecast horizon.

${ }^{5}$ Further details about LP IRF techniques can be found in Jordà (2005).

${ }^{6}$ The decline in the real housing returns when the global economy is expanding could be due to portfolio reallocation of investors away from the real estate market into other markets such as the oil market to derive profits from their increased prices (Sheng et al., forthcoming).
} 
increases, leads to increase in real housing returns. In contrast, a speculative oil-specific consumption demand shock and precautionary oil inventory demand shock increase oil price and reduces state-level real housing returns, since these shocks are generally regarded as negative news that adversely influences economic activities and lowers housing prices because of reduced housing demand (Sheng et al., forthcoming). Finally, with all the shocks being of the same magnitude, i.e., 1-unit, we find that the strongest initial impact results from the economic activity shock, followed by the effect from the oil inventory demand shock, and then the oil-specific supply and demand shocks. ${ }^{7}$

\section{[INSERT FIGURE 1 ABOUT HERE]}

Next, in Figure 2, we re-analyse the impact of the four structural shocks with the IRFs now contingent on the oil dependence of the states, derived based on the nonlinear model outlined in equations (2) and (3). As can be seen, the behaviour of real housing returns due to the four shocks is in general qualitatively similar to those derived from the linear model as reported in Figure 1, but now relatively smoother, possibly due to the imposition of the smooth transition function. But, more importantly, we do not find the impulse responses to reverse in sign across the high and low oil-dependence states, although the size of the impacts is relatively muted under the low-oil dependence regime, barring in the case of the oil inventory demand shock. The similarity of the sign is an indication that for the net oil-producing regions, the effect of increases in oil price due to a negative oil supply shock or positive speculative and precautionary oil demand shocks are not strong enough to cause windfall gains to increase housing demand and house prices. As far as the relatively stronger impact on the real housing returns of the high-oil dependence states is concerned, this is not surprising since, these states are the ones that can basically be considered as oil-importers, or more precisely these are regions that consume more oil than they produce. Naturally, it is expected that in these states, a positive oil-specific supply shock (resulting in a fall in oil prices) and a negative oil-specific consumption demand shock (associated with a rise in oil prices) is likely to have a relatively stronger increase and decrease in real housing returns respectively. The stronger positive impact of the global economic activity shock on real housing returns of the high oil dependence states is an indication that the world growth is driven by the increase in overall productivity, and hence raises revenues of various sectors of the economy rather than just the oil sector, to the extent that the effect on the low oil dependence states (whose economies are primarily run only by oil (De Michelis et al., 2020; van Eyden et al., forthcoming)) is statistically insignificant. Finally, the relatively stronger negative impact on real housing returns from the precautionary oil inventory demand shock for the oil-rich states seem to suggest that an increase in inventory is perceived as a weaker negative news in the high oil-dependence states, confirming the above line of reasoning that the effect of increases in oil price is not strong enough to raise real housing returns (via increases in income).

\section{[INSERT FIGURE 2 ABOUT HERE]}

\footnotetext{
${ }^{7}$ When we applied the model to the 384 Metropolitan Statistical Areas (MSAs), with data (on house prices and the $\mathrm{CPI}$ ) derived from the same sources as that of the states in constructing real housing returns, we obtained qualitatively similar results due to the four oil price shocks, as depicted in Figure A1 in the Appendix of the paper. Interestingly, if we conducted a time series-based analysis on the overall real housing returns of the US (with data derived from the same sources as the states and MSAs), as depicted in Figure A2 in the Appendix of the paper, only oil-specific supply and demand shocks have significant positive and negative impacts respectively. In the process, our results highlight the importance of accounting for the heterogeneity in the housing sector of the US via a panel data-based approach, since the housing market cannot be considered as a single-market (Del Negro and Otrok, 2007).
} 


\section{Conclusion}

In this paper, we analyse the impact of disaggregated oil (supply, global economic activity, oilspecific consumption demand and oil inventory demand) shocks on state-level real housing returns of the US over the monthly period of 1975:M02 to 2019:12. We find that, even though economic activity shock raises oil price due to increase in global demand, real housing returns is found to be impacted strongly in the positive direction, the magnitude of which outweighs the positive impact of an increase in oil production shock (resulting in a decrease in oil price), and the negative effects associated with oil-specific consumption demand and oil inventory demand shocks, which raises oil price. In addition, we find that the oil dependence of the states, defined as oil consumed minus oil produced as ratio of oil consumed, does not change the nature of the impact of the four oil shocks on real housing returns drastically, but the size of the effects is relatively muted under low-oil dependence, barring the case of the oil inventory demand shock. From a policy perspective, our results imply that policymakers would need to undertake the strongest expansionary policies when the decline in real housing returns is due to a fall in global demand for oil because of shrinking economic activity, which could be further intensified due to declining real estate prices. Moreover, with the size of the impact of the oil shocks contingent on oil dependence across the states, policymakers would need to design regime-specific policy measures to revive real housing returns in the case the oil shocks negatively impact the sector. As part of future research, it would be interesting to extend our analysis to a cross-country level involving oil-exporters and oil-importers, and also analyse possible second moment impact on housing prices as discussed in Gupta et al., (2020).

\section{References}

Agnello, L., Castro, V., Hammoudeh, S. and Sousa, R.M. (2017) Spillovers from the oil sector to the housing market cycle. Energy Economics, 61, 209-220.

Anari, A. and Kolari, J.W. (2002). House Prices and Inflation. Real Estate Economics, 30(1), 67-84.

Antonakakis, N., Gupta, R., and Muteba Mwamba, J.W. (2016). Dynamic Comovements between Housing and Oil Markets in the US over 1859 to 2013: A Note. Atlantic Economic Journal, 44(3), 377-386.

Auerbach, A.J., and Gorodnichenko, Y. (2013). Fiscal Multipliers in Recession and Expansion, in: Alesina, A., and Giavazzi, F. (eds.), Fiscal Policy after the Financial Crisis, University of Chicago Press, 63-98.

Aye, G.C., Clance, M.W., and Gupta, R., (2019). The Effect of Economic Uncertainty on the Housing Market Cycle. Journal of Real Estate Portfolio Management, 25(1), 67-75.

Balcilar, M., Gupta R., and Miller S.M. (2014). Housing and the Great Depression. Applied Economics, 46(24), 2966-2981.

Baumeister, C., and Hamilton, J. D. (2019). Structural interpretation of vector autoregressions with incomplete identification: Revisiting the role of oil supply and demand shocks. American Economic Review, 109(5), 1873-1910.

Baumeister, C., Peersman, G., and van Robays, I. (2010). The Economic Consequences of Oil Shocks: Differences across Countries and Time, in: Fry, R., Jones, C., and Kent, C. (eds.), Inflation in an Era of Relative Price Shocks, Reserve Bank of Australia, 91-128.

Bodenstein, M., Guerrieri, L., and Kilian, L. (2012). Monetary Policy Responses to Oil Price Fluctuations. IMF Economic Review, 60(4), 470-504.

Bonato, M. (2019). Realized correlations, betas and volatility spillover in the agricultural commodity market: What has changed? Journal of International Financial Markets, Institutions and Money, 62, 184-202. 
Breitenfellner, A., Cuaresma, J.C., and Mayer, P. (2015). Energy inflation and house price corrections. Energy Economics, 48, 109-116.

Chan, K.F., Treepongkaruna, S., Brooks, R., and Gray, S. (2011). Asset market linkages: Evidence from financial, commodity and real estate assets. Journal of Banking \& Finance, 35(6), 1415-1426.

Christou, C., Gupta, R., Nyakabawo, W., and Wohar, M.E. (2018). Do house prices hedge inflation in the US? A quantile cointegration approach. International Review of Economics \& Finance, 54(C), 15-26.

De Michelis, A., Ferreira, T. and Iacoviello, M. (2020). Oil prices and consumption across countries and US states. International Journal of Central Banking, 16(2), 3-43.

Del Negro, M., and Otrok, C. (2007). 99 Luftballons: Monetary Policy and the House Price Boom across US States. Journal of Monetary Economics, 54(7), 1962-85.

Emirmahmutoglu, F., Balcilar, M., Apergis, N., Simo-Kengne, B.D., Chang, T., and Gupta, R. (2016). Causal Relationship between Asset Prices and Output in the US: Evidence from StateLevel Panel Granger Causality Test. Regional Studies, 50(10), 1728-1741.

Grossman, V., Martínez-García, E., Sun, Y., and Torres, L.B. (2019). Drilling Down: The Impact of Oil Price Shocks on Housing Prices. The Energy Journal, 40, Uncertainty and Recent Challenges in Oil and Commodity Markets Special Issue, 59-84.

Gupta, R., Sheng, X., and Ji, Q. (2020). Movements in real estate uncertainty in the United States: the role of oil shocks. Applied Economics Letters. DOI: DOI: https://doi.org/10.1080/13504851.2020.1796911.

Gupta, R., Sheng, X., van Eyden, R., and Wohar, M.E. (Forthcoming). The Impact of Disaggregated Oil Shocks on State-Level Consumption of the United States. Applied Economics Letters.

Gupta, R., and Wohar, M.E. (2017). Forecasting oil and stock returns with a Qual VAR using over 150 years of data. Energy Economics, 62(C), 181-186.

Jordà, Ò. (2005). Estimation and Inference of Impulse Responses by Local Projections. American Economic Review, 95 (1): 161-182.

Jordà, Ò., Schularick, M., and Taylor, A.M. (2020). The effects of quasi-random monetary experiments. Journal of Monetary Economics, 112, 22-40.

Kilian, L. (2009). Not all oil price shocks are alike: disentangling demand and supply shocks in the crude oil market. American Economic Review, 99, 1053-1069.

Killins, R.N., Egly, P.V., and Escobari, D. (2017). The impact of oil shocks on the housing market: Evidence from Canada and U.S. Journal of Economics and Business, 93, 15-28.

Leamer, E.E. (2007). Housing is the business cycle. Proceedings, Economic Policy Symposium, Jackson Hole, Federal Reserve Bank of Kansas City, pages 149-233.

Leamer, E.E. (2015). Housing really is the business cycle: what survives the lessons of 200809? Journal of Money, Credit and Banking, 47(S1), 43-50.

Nazlioglu, S. Gormus, N.A., and Soytas, U. (2016). Oil prices and real estate investment trusts (REITs): Gradual-shift causality and volatility transmission analysis. Energy Economics, 60(C), 168-175.

Nazlioglu, S., Gupta, R., Gormus, N.A., and Soytas, U. (2020). Price and volatility linkages between international REITs and oil markets? Energy Economics, 88, 104779.

Nyakabawo, W.V., Miller, S.M., Balcilar, M., Das, S. and Gupta, R. (2015). Temporal Causality between House Prices and Output in the U.S.: A Bootstrap Rolling-window Approach. North American Journal of Economics and Finance, 33(1), 55-73.

Plakandaras, V., Cunado, J., Gupta, R., Wohar, M.E. (2017). Do leading indicators forecast U.S. recessions? A nonlinear re-evaluation using historical data. International Finance, 20(3), 289-316. 
Sheng, X., Marfatia, H.A, Gupta, R., and Ji, Q. (Forthcoming). House Price Synchronization across the US States: The Role of Structural Oil Shocks. The North American Journal of Economics and Finance.

van Eyden, R., Gupta, R., and Wohar, M.E. (Forthcoming). Impact of Oil Price Volatility on State-Level Consumption of the United States: The Role of Oil Dependence. Energy Exploration and Exploitation. 
Figure 1. Response of State-Level Real Housing Returns to the Four Structural Oil Shocks
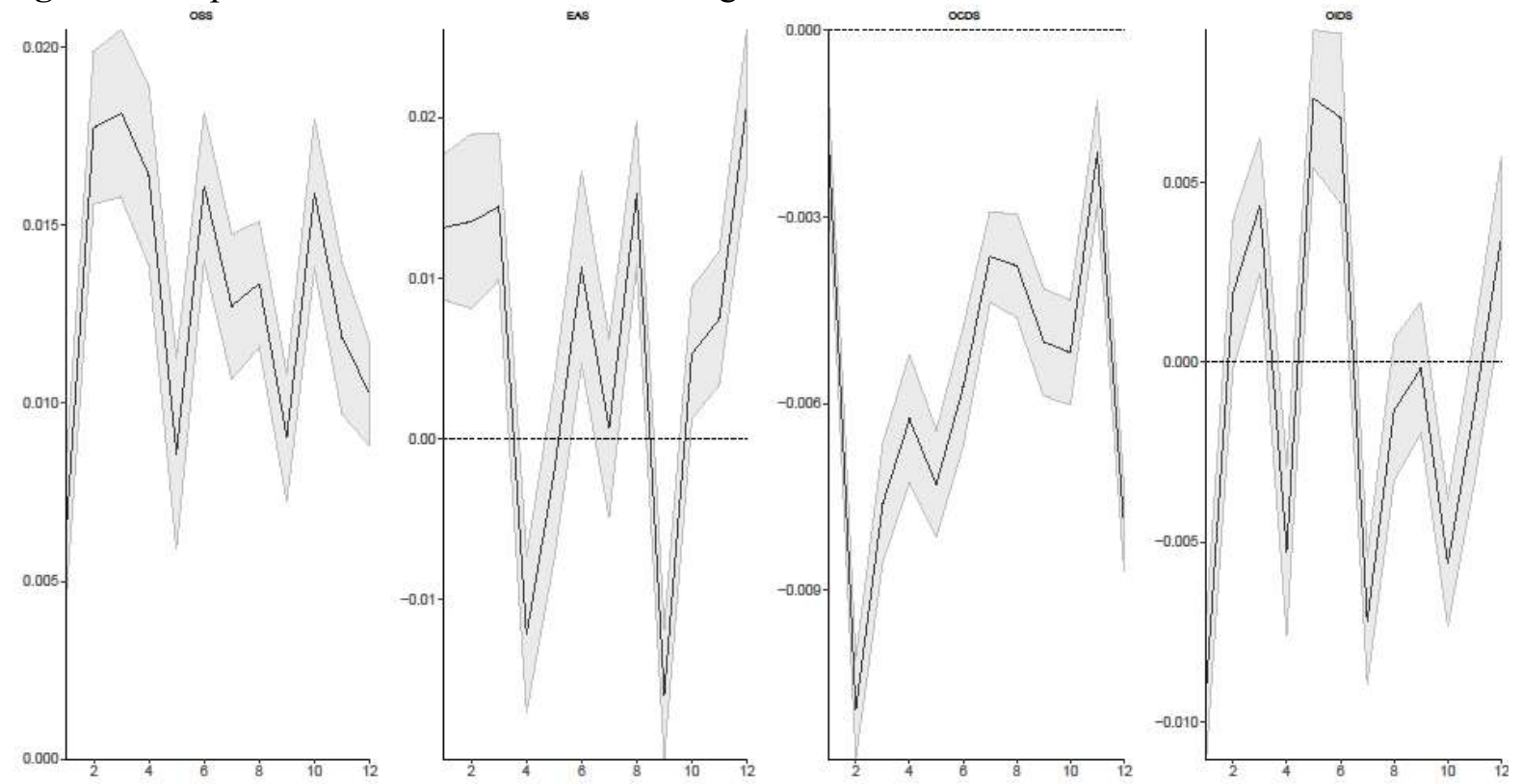

Note: OSS represents oil supply shock; EAS represents global economic activity shock; OCDS represents oilspecific consumption demand shock; OIDS represents oil inventory demand shock. The figures show the impulse response of state-level real housing returns to a 1 unit increase in a specific disaggregated oil shock. The shaded areas represent the $95 \%$ confidence bands.

Figure 2. Response of State-Level Real Housing Returns to the Four Structural Oil Shocks Contingent on High (high) and Low (low) Oil-Dependence
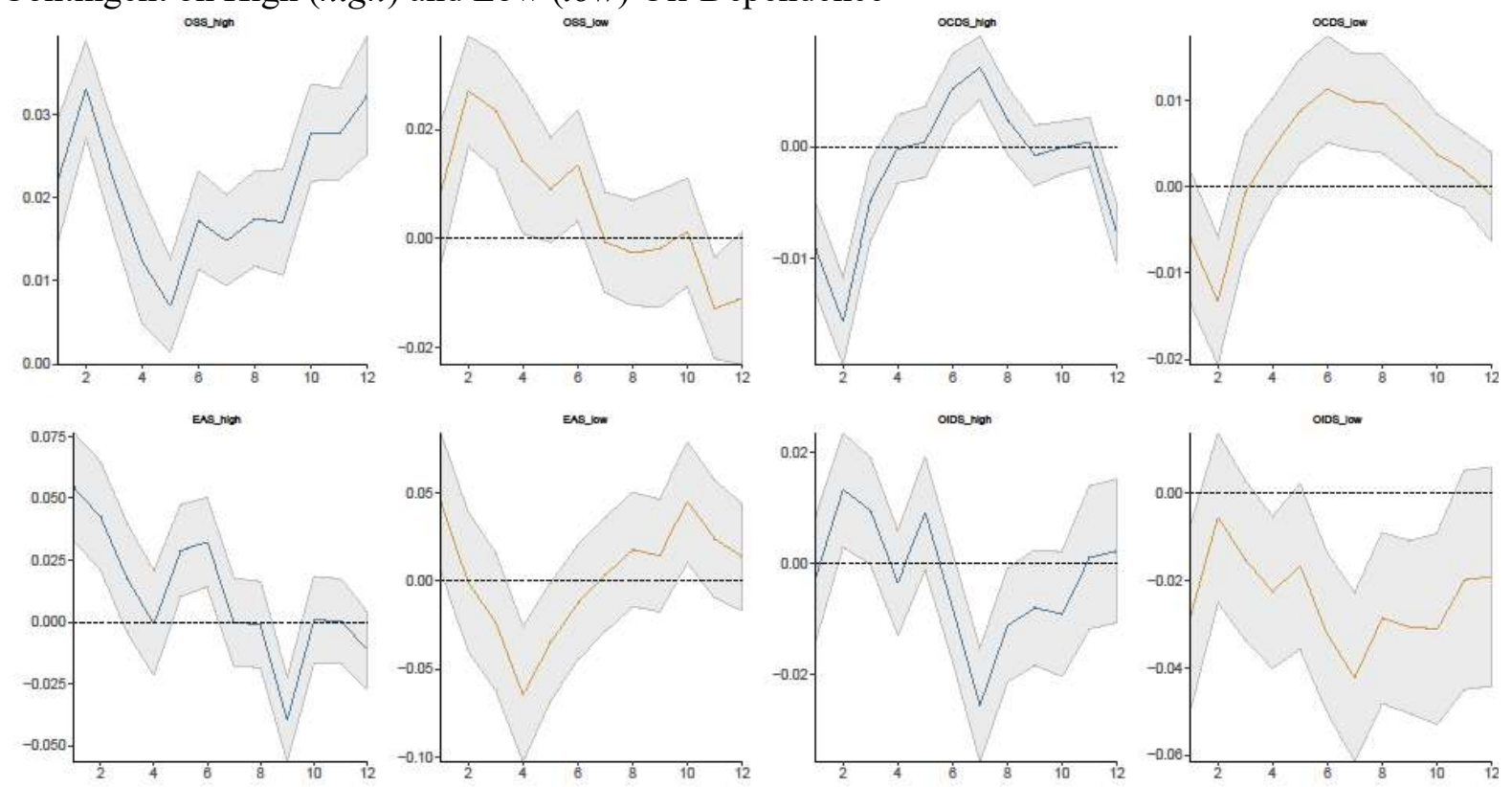

Note: See Notes to Figure 1. Oil Dependence: oil consumed minus oil produced as a percentage of oil consumed, with high and low corresponding to high- and low-levels of oil dependence respectively. 


\section{Appendix}

Figure A1. Response of MSA-Level Real Housing Returns to the Four Structural Oil Shocks
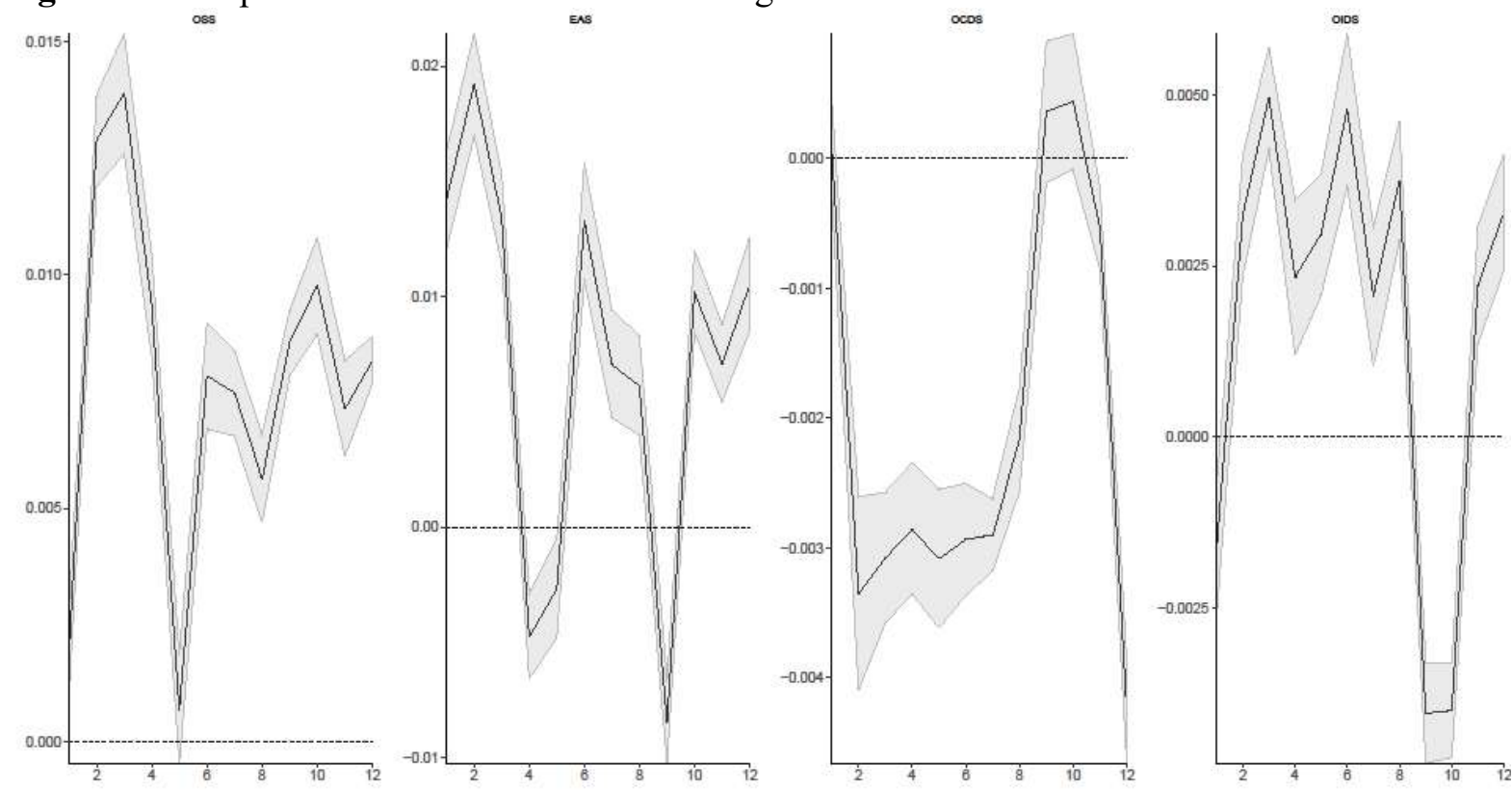

Note: See Notes to Figure 1.

Figure A2. Response of Aggregate US-Level Real Housing Returns to the Four Structural Oil Shocks
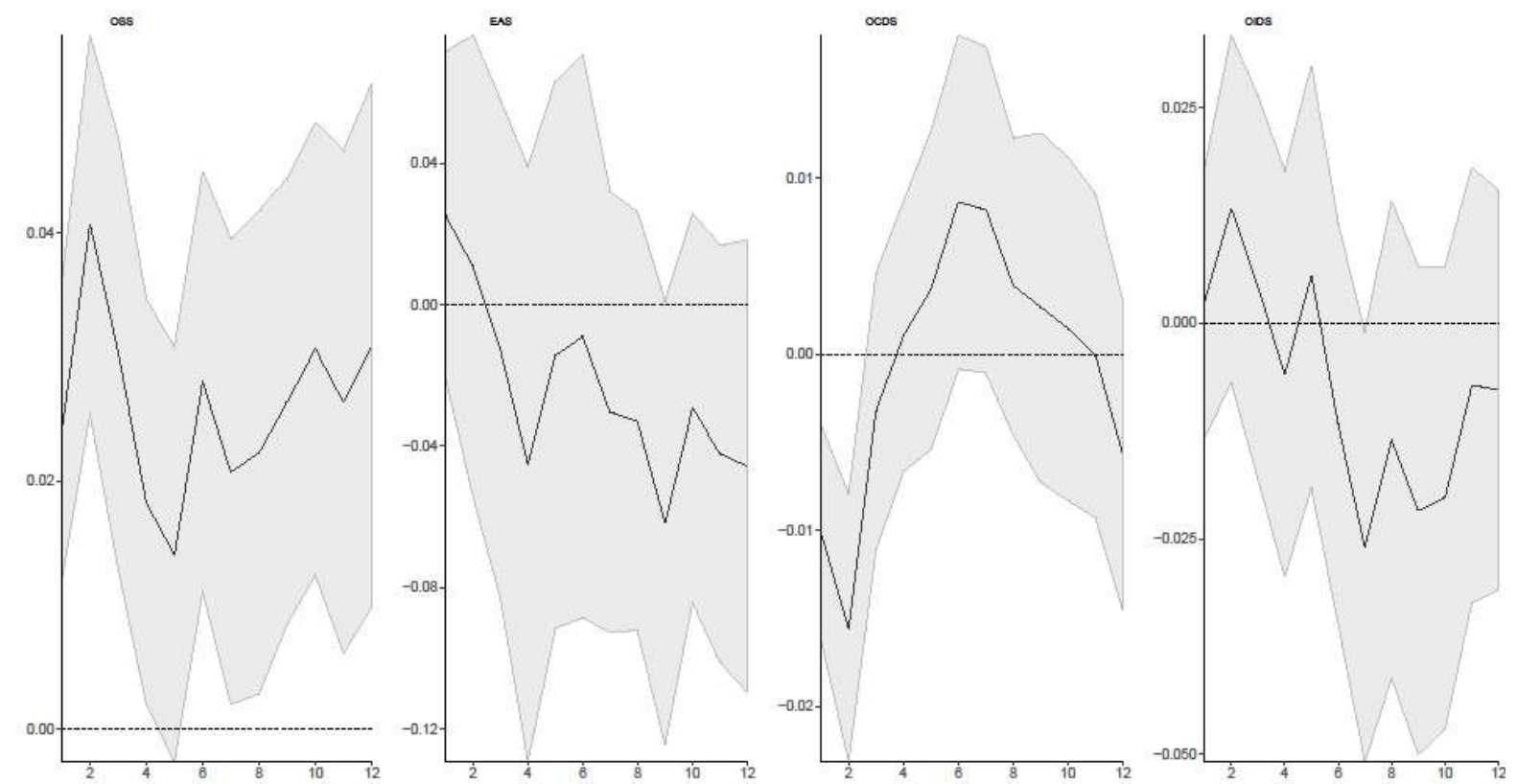

Note: See Notes to Figure 1. 